\title{
The Association Of Changes In Self-Regulated (Voluntary) Disclosures Of Business Strategy And The Going Concern Opinion
}

Peter M. Theuri (Email: THEURI@exchange.nku.edu), Northern Kentucky University

\begin{abstract}
While a majority of research has pointed to management's engagement in earnings management through accruals and choices in accounting methods, only recently have studies investigated similar practices through voluntary disclosures of firm performance and/or future business strategies disclosed by management as part of their annual reporting. Since a firm's future survival comes into question when a firm receives a going concern audit opinion, the key question is whether the presence of such an opinion can be associated with changes in self-regulated disclosures of business strategy. Considering such bad news in light of management's freedom to discuss their views of firm performance voluntarily offers a great opportunity for disclosure management.
\end{abstract}

This study investigates the association between changes in self-regulated (voluntary) disclosures of firm performance through articulation of future business strategy and the presence of a going concern audit opinion. An experimental sample of 55 firms receiving a first-time going concern opinion is compared to a sample of 55 control firms not receiving a going concern opinion. Data for a period of four years after the first-time going concern opinion is received is analyzed to provide 220 firm years for each sample of the 55 firms. A score representing self-regulated disclosures of business strategy (dependent variable) derived from content analysis performed on sections of the annual report is used.

Results indicate that management begins to disclose more defender type of business strategies about two years prior to the year of the first-time going concern opinion. It may be an indicator that auditors begin expressing concerns about the firm's ability to survive as far back as two years prior to their issuance of the first-time going concern opinion. Overall results indicate a negative association between management's tendency to disclose prospector type strategies and the firsttime receipt of a going concern opinion.

\section{Introduction}

$T$ he Generally Accepted Accounting Principles mandate and promote the concept of "objectivity" in reporting. While a majority of research has pointed to management's engagement in earnings management through accruals and choices in accounting methods, only recently have studies investigated voluntary disclosures of firm performance and/or future business strategies that management wishes to disclose as part of their annual reporting. While financial statements included in the annual report must be subjected to an audit, other management discussions and letters included in the annual report do not go through such rigor. The auditor is only required to read those other disclosures to ensure that they do not contradict the information

Readers with comments or questions are encouraged to contact the author via email. 
contained in the financial statements. When a firm receives a going concern audit opinion, its future survival comes into question. Such a threat (bad news to interested parties) when considered in light of management's freedom to voluntarily discuss their views of firm performance, offers a great opportunity for disclosure management. The key question is whether the presence of a going concern audit opinion that questions the future survival of a firm can be associated with changes in self-regulated (voluntary) disclosures of business strategy.

Until recently, most accounting research using the non-financial performance measures has been descriptive in nature (Bagby et al. 1988; Dieter and Sandefur 1989; Gibson and Schroeder 1990). Recent studies have begun quantifying non-financial information taken from the management and discussion analysis (MD\&A) section of annual reports and incorporating this information into models that answer various questions (Anderson 1998; Ittner et al. 1997; Botosan 1997; Bryan 1997, Gosselin 1997). Other research has examined the relevance of non-financial information from sources other than the management discussion and analysis section of the annual report. Lev and Thiagarajan (1993), for example, identify fundamental issues from analysts' descriptions and test both their value-relevance and predictive ability (for future earnings). Amir and Lev (1995) test the value-relevance of non-financial information in the wireless communication industry. Both of these studies show evidence of an association between certain non-financial information and returns, after controlling for financial information, such as earnings. With the increase in the use of these approaches comes the need to assess any GCO association with changes in disclosed business strategies.

Management disclosures of choices in strategy, a non-financial variable, have been found to provide useful information about a variety of topics. Botosan (1997) found that management disclosure level reduced the cost of capital. In her study, she quantified management's disclosed strategies among other disclosures. Ittner et al. (1997) also quantified management strategy by adopting the Miles and Snow (1978) strategy typology. In their study, Ittner et al. (1997) sought to find the factors influencing the weights placed on both financial and non-financial performance measures in CEO annual bonus contracts. Interestingly, they found that firms pursuing an innovationoriented prospector strategy tend to place greater weight on non-financial performance in their annual bonus contract. Gosselin (1997) examined the effect of strategic posture and organizational structure on the adoption and implementation of activity-based costing. In all these examples, it is clear that non-financial measures have the potential to convey information beyond that provided by financial statements. Asare (1990) called for future research to explore the impact of going-concern reporting on, among others, suppliers of debt capital, and the client's investment/production decisions.

The disclosed business strategies of a sample of firms receiving a first-time GC are compared to those of a cross-sectional sample of similar firms receiving unqualified audit opinions and to time series measures of business strategy of the experimental firms in the years before a first-time GC.

While the effects of a GC on stock prices has been studied extensively, little empirical evidence exists regarding management's strategic response to the auditor's issuance of a first-time GC. This study assumes that management is cognizant of the auditor's responsibility to consider the firm's business strategy in making a judgment about the ability of the firm to continue as a going concern. This study also assumes management's awareness of the auditor's decision to issue a first-time GC and that such awareness will prompt an evaluation and an adjustment of the firm's disclosed business strategy. The adjusted strategies are then communicated (disclosed) externally as part of the annual report. Snow and Hambrick (1980) point out that organization and management theorists view strategy as the mechanism which guides environmental alignment and provides integration for internal operations. In discussing flexible reporting, the Jenkins Committee Report points to the need for users to see a company through the eyes of management to help them understand management's perspective and predict where management will lead the company (AICPA 1994). 


\section{Methodology}

Experimental Design and Sample Selection

This study uses: (1) 55 experimental firms receiving a first time going concern opinion (GC) and (2) 55 control firms that did not receive a GC during the study periods. Selected control firms capture industry representation, financial health status, and year through a matching process that considered the event year, two digit SIC codes, and level of financial distress (in that sequence). Firms in the same industry tend to face the same contracting and financial reporting problems, and are therefore expected to use similar accounting and reporting practices (Christie and Zimmerman 1994; DeChow et al. 1995; Sweeney 1994). These firms also tend to change accounting procedures at the same time due to changing macro-economic conditions and/or changes in the ex ante optimal set of accounting procedures (Sweeney 1994). Given this association, matching the control sample firms to the experimental firms by event year, industry, and financial distress provides a more consistent evidence of any association effects of a GC on the experimental firms' strategy disclosure practices. The $\mathrm{b}^{*}$ statistic from the Zmijewski (1984) weighted probit bankruptcy prediction model is used as the surrogate for capturing financial distress.

The sample of experimental, actively traded U.S. firms that received a first-time GC during the period 1989 through 1994 was used to examine the relationship between a firm's business strategies and its audit outcome related distress. The primary source of sample firms COMPUSTAT PC database. When a firm with a going concern qualification was found, the audit opinion for each prior period was examined to determine whether the previous year's opinion was qualified until an unqualified opinion was found and a first-time GC was considered established if each of the experimental firm's audit opinions for the three prior years was unqualified. This procedure was necessary in establishing the year of first-time qualification. The control sample firms were restricted to those firms reporting an unqualified audit opinion in the COMPUSTAT PC database for all four years.

Non-quantitative type data was gathered from the firm's annual report. The annual report is generally considered to be one of the most important sources of corporate information (AICPA 1994; Botosan 1997). In addition, management is most likely to use this medium of communication to provide shareholders with information that may help to counteract some of the negative perceptions that the auditor's opinion may convey.

Three criteria were used in constructing a sample of experimental firms with a first-time GCO: (1) The firm received a first-time GC during the period January 1, 1989 and December 31, 1994. (2) The firm was not a financial, insurance, or real estate company, in that these firms require unique accounting practices and also operate in unique economic environments that may not lend firm characteristics to be comparable with other firms in the sample (Bell and Tabor 1991; Jones 1996). (3) The firm did not declare bankruptcy, nor was it in liquidation process three years before or in the year of the first-time GCO.

\section{Data Analysis Techniques}

A cross-sectional test of the effects of a going concern modification on the firm's business strategy is performed for the year of a first-time GC as compared to a control sample of firms from similar industry, the same year, and in similar states of financial distress. An ordinary least squares (OLS) multiple regression model is used to evaluate the effect of a GC on the measure of business strategies. The cross-sectional model is estimated using data from both the experimental firms and control firms matched on year, industry, and level of financial distress. The cross-sectional model is:

$$
S T R A T_{i}=b_{0}+b_{1} \text { OPIN }_{i}+b_{2} F D I S_{i}+b_{3} I N D_{i}+b_{4} S T A B_{i}+\varepsilon_{i}
$$


where:

$\begin{array}{lll}\begin{array}{l}\text { STRAT } \\ \text { OPIN }\end{array} & = & \begin{array}{l}\text { a measure for business strategy } \\ \text { coded as } 1 \text { for a firm receiving a going concern } \\ \text { opinion and } 0 \text { for a clean opinion } \\ \text { controls for overall financial health of the firm } \\ \text { using Zmijewski's } b^{*} \text { statistic. }\end{array} \\ \text { FDIS } & =\quad \begin{array}{l}\text { controls for firm's position in its industry - also } \\ \text { captures industry dominance (dynamism). It is measured as the standardized } \\ \text { deviation of a firm's sales to industry ratio from the industry mean sales ratio. } \\ \text { controls for the stability of management (coded } \\ \text { as 1 for a change in management for firm } i, \text { and } 0 \text { for no change in management) } \\ \text { a random disturbance term representing other } \\ \text { factors that may influence STRAT }\end{array}\end{array}$

The regression coefficient $\left(b_{1}\right)$ measures the effect of the going concern modification on business strategy, and provides the tests of hypothesis.

To provide an examination of the similarities/differences between the experimental firms and control firms in the years when both received unqualified audit opinions, model 1is estimated cross-sectionally over each of the three prior years. The dummy variable, OPIN in model lis replaced with the dummy variable, TYPE in model 2 since both the experimental firms and the control firms each received unqualified opinions in these years. TYPE is coded as 1 for those firms that received a GC in year $\mathrm{t}(0)$ and coded 0 for control firms. The cross-sectional model with the dummy variable, TYPE is:

$S T R A T_{i}=b_{0}+b_{1} T Y P E_{i}+b_{2} F D I S_{i}+b_{3} I N D_{i}+b_{4} S T A B_{i}+\varepsilon_{i}$

\section{Variables}

\section{Dependent Variable}

Business Strategy (STRAT): The measure STRAT was obtained by using a content analysis technique to analyze and measure the information management disclosed in annual reports to shareholders. While Snow and Hambrick (1980) offer four alternative strategy measurement approaches which they suggest may be used in combination to capture business strategy for an organization, a combination of investigator inference and objective indicators approaches were utilized to arrive at an appropriate cross-sectional score for an organization's business strategy. The reliance on a combination of these techniques may be most advantageous (Shrivastava and Nachman 1989; Snow and Hambrick 1980; Young 1989). The selection of items to include in measuring STRAT was guided by strategic management literature's definition of strategy typologies and their inherent natures (see Figure 1). The items included in strategy reflect ten broad categories and 27(26) prospector (defender) specific categories of information discussed in annual reports and considered to be indicative of a particular type of business strategy. Similarly, Bell et al. (1997) provide eight components of the client business model used by auditors to organize and integrate information gathered about the client's business and industry. Each disclosed strategy was awarded one point towards either prospector strategy or defender strategy depending on how it is defined within the strategy literature. When disclosed in quantifiable terms, an additional point was awarded. Botosan (1997) weighed her disclosure score similarly, arguing that precise information is more useful and may enhance management's reporting reputation and credibility. The Jenkins Committee Report (AICPA 1994) suggests that while business events are important, numbers are important as well. Additionally, the report urges managers to supplement qualitative disclosures with quantitative measurements where practical and meaningful if those measurements are sufficiently reliable for external presentation.

A proportion of the total responses representing the disclosed business strategy is used as the dependent variable. This proportion is anchored within a continuum of $[0,1]$ based on a ratio of total prospector points awarded 
to the total points awarded to both prospector and defender disclosed strategies. A STRAT score of one, therefore, is an indicator of a firm disclosing only prospector strategy tendencies and no identifiable defender strategies, while a STRAT score of zero indicates a firm whose disclosures all reflect a defender strategy. The proportion of STRAT points earned by a given firm $i$ were computed by the following formula:

$$
S T R A T=\frac{\sum_{j=1}^{27} S C O R E_{p j}}{\sum_{j=1}^{27} S C O R E_{p j}+\sum_{j=1}^{26} S C O R E_{d j}}
$$

Strategy for firm $i$ is computed as the ratio of the sum of firm $i$ 's prospector strategy scores (SCORE $\left.{ }_{p}\right)$ across all elements $j=1,27$ to the combined sum of firm $i$ 's prospector and defender strategy scores, as shown in the formula above, with the $i$ subscript suppressed.

Explanatory and Control Variables:

1. OPINION (OPIN): The audit-outcome related distress variable, OPIN, captures whether or not the firm received a first-time going concern opinion (GC) and dichotomously coded as 1 for firm-years with a first-time GC, and 0 for firm-years with unqualified opinions. For year $\mathrm{t}(0), O P I N$ is coded as one for each experimental firm and as zero for each control firm.

2. TYPE (TYPE): In the cross-sectional test involving experimental and control firms over the three years preceding year $\mathrm{t}(0), O P I N$ is replaced by TYPE. TYPE is coded as 1 for experimental firms and as 0 for control firms. TYPE is used to capture any inherent cross-sectional difference that existed between the experimental and control firms in the years before the experimental firms received their first-time GC.

3. FINANCIAL DISTRESS (FDIS): FDIS captures the financial health of the firm. The $b^{*}$ statistic from the Zmijewski (1984) weighted probit bankruptcy prediction model is used as a surrogate for financial distress ${ }^{1}$. According to Jones (1987) all ratio-based prediction models yield very similar bankruptcy probabilities.

4. INDUSTRY DOMINANCE (IND): This variable controls for the firm's market position within its industry. It controls for the firm's competitiveness and its ability to influence its industry's strategic directions. The (firm sales/industry sales) ratio is used as a proxy variable for industry dominance and is calculated as explained below. In keeping with Bell and Tabor (1991), the sales ratio is calculated in industry-standardized form:

$S T\left(\mathrm{X}_{i, t}\right)=\left[\mathrm{X}_{i, t}-\mathrm{X}_{I, t}\right] / S D\left(\mathrm{X}_{I, t}\right)$

where: $S T\left(\mathrm{X}_{i, t}\right)=$ the deviation of a firm's ratio $\mathrm{X}$ for the year $t$ from the industry mean ratio $\mathrm{X}_{I}$ for year $t$, divided by the standard deviation of ratio $X$ across firms in industry $I$ for year $t$. This variable was estimated using all firms found on COMPUSTAT PC database within the same four-digit Standard Industrial Classification (SIC) code as firm $i$.

5. MANAGEMENT STABILITY (STAB): This corporate governance variable, STAB, controls for changes in strategy due to management turnover (changes in managerial continuity). Strategy is assumed to be associated with, and dependent on, the current management's political strength as measured by the term of service (stability). Changes in management, especially the CEO, will increase uncertainty about a firm's future business strategy and its managerial expertise.

\footnotetext{
${ }^{1}$ The $b^{*}$ figure is calculated as follows: $b^{*}=-4.803-3.6$ (net inc./assets) $+5.4($ debt/asset $)-.1$ (curr. assets/curr. liab)
} 
As a control for management stability, any changes in the firm's key management (president, CEO, chairman of the board) that have occurred within the year are used in measuring STAB. STAB is dichotomously coded as 1 when a firm experienced a management change and 0 otherwise. DeFond and Jiambalvo (1994) found that firms with increased monitoring and also a debt covenant violation experienced management change in the year of covenant violation.

\section{Data Analysis And Results}

\section{Descriptive Profile of Sample Firms}

The entire sample of 110 firms represents five broad SIC defined industries with the majority (62\%) of the firms in the manufacturing industry. Where a match firm was not found within its immediate two-digit industry classification, the closest broader industry group was used to select a match. Firms in the 6000-6799 SIC industrial classification category were not included in analysis since this category includes financial institutions and real estate company firms. These industries require unique accounting and reporting procedures that may not be ideally comparable with firms in the other industries (Bell 1991; Jones 1996).

The average STRAT score for the experimental firms over the four years was 0.6183. This STRAT measure suggests that on the average these firms disclosed slightly more prospector-type strategies than defender-type strategies over the four-year period. The modal or most often occurring STRAT ratio over the four year period was 0.5000 suggesting that it is not uncommon for firms to disclose an equal number of prospector-type and defendertype strategies.

When the mean STRAT is computed for the experimental firms in the year of GC only, there is a drop in the mean, mode, and median STRAT scores, suggesting that these experimental firms adjusted their strategy towards disclosing more defender than prospector type strategies in year $\mathrm{t}(0)$. When the score is computed for three years preceding the year of GCO, the mean, mode, and median STRAT scores are higher. This finding could be expected since the firms do not face a threat of a GC in those years.

Statistics for the control firms shows that the mean STRAT score is slightly less than that in experimental firms (preceding three years) but that this score is still higher than those reported for all experimental firms. The tendency is for control firms to report more of prospector than defender type strategies over the four-year period.

It is clear from these statistics that the experimental firms started out as more prospector type and adjusted their disclosed strategy towards more defender type by the year of the GC. This behavior is also graphically reported in Figure 1, which plots the mean STRAT score by event year for both the experimental, and control firms. As experimental firms move closer to year $\mathrm{t}(0)$, they clearly disclose more of defender than they do prospector strategies. In fact, it appears as if this behavior begins about two years before the year of GC. It is possible that the auditors start raising going-concern type issues in earlier years although a GC is not issued until $t(0)$. While the control firms also report less of prospector than defender strategies in year $\mathrm{t}(-1)$, the experimental firms clearly disclose more defender than prospector strategies as compared to the control firms in years $t(-1)$ and $t(0)$.

Table 1 presents comparative annual descriptive statistics for both the 55 experimental firms (firms with a first-time GC) and the 55 control firms (firms with an unqualified opinion for each of the four years in this study). This table presents a comparison of each variable's mean statistic for the firms with a first-time GC in year $\mathrm{t}(0)$ with that of the control firm that did not receive a GC in any of the four years. An independent samples t-test is performed on these mean statistics. Panel A presents statistics for the dependent variable (STRAT) for each of the four years. 
Figure 1: Mean STRAT score by event year for experimental (GC) and control (UNQ) firms

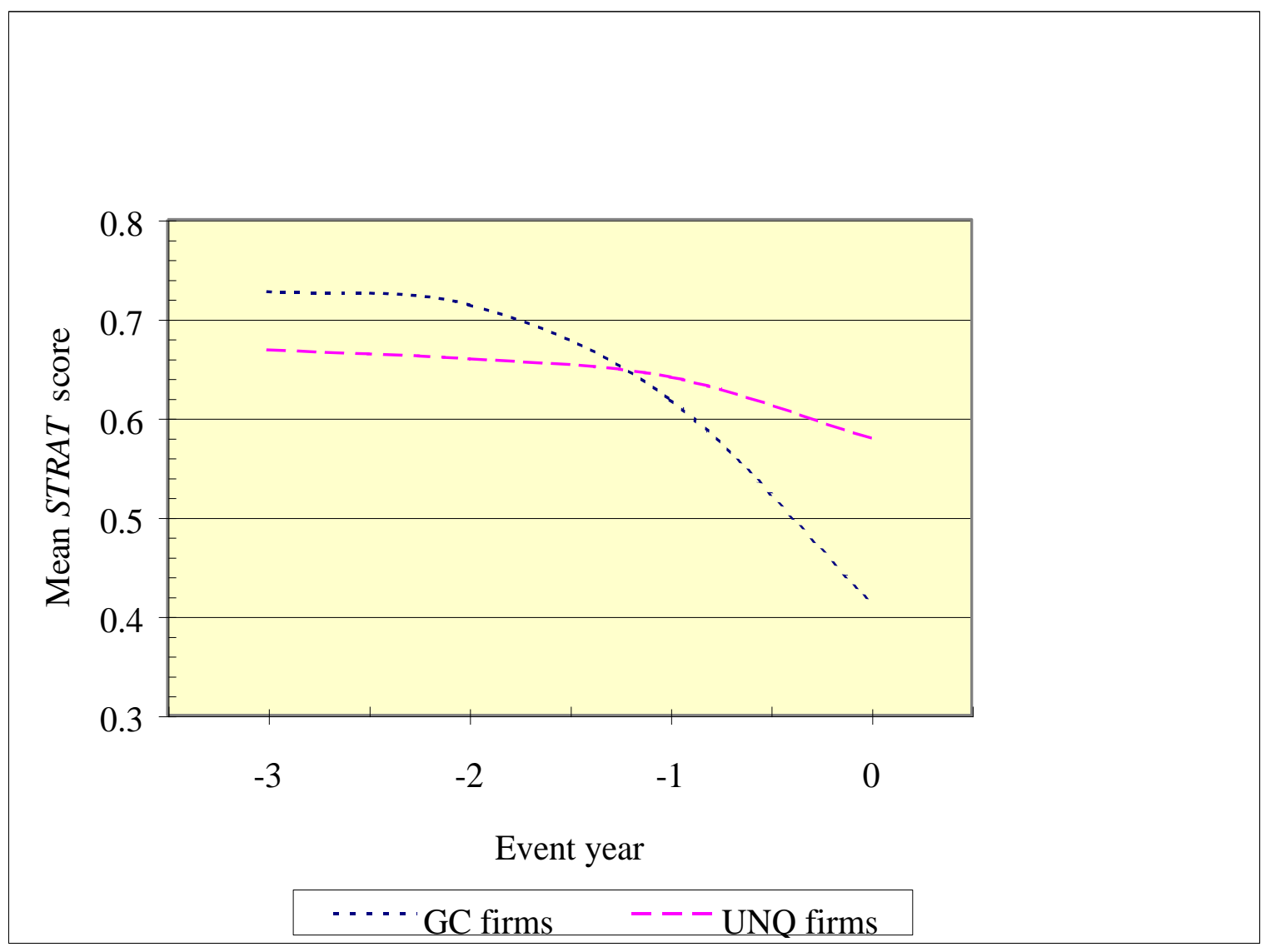


Company:

Opinion:
STRAT:

Fiscal Year: ___ Event Year:

\section{ELEMENTS OF BUSINESS STRATEGY}

\begin{tabular}{|c|c|c|c|c|c|}
\hline & PROSPECTORS & Pts. & & DEFENDERS & Pts. \\
\hline \multirow{4}{*}{ PRODUCTS } & & & PRODUCTS & & \\
\hline & New Products & 12 & & Low Product Diversity & 12 \\
\hline & Wide Product Market & 12 & & Narrow Product Market & 12 \\
\hline & & & & High Production Volume & 12 \\
\hline \multirow[t]{3}{*}{ MARKETING } & Marketing Driven & 12 & MARKETING & Extend Current Product & 12 \\
\hline & Emphasize Selling & 12 & & Less Emphasis on Promotion & 12 \\
\hline & Sales Forecasting (aggressiveness) & 12 & & & \\
\hline \multirow[t]{2}{*}{ ALLIANCES } & & & ALLIANCES & Limited Alliances & 12 \\
\hline & Established Alliances & 12 & & Unstable Alliances & 12 \\
\hline \multirow[t]{6}{*}{ OPERATIONS } & Moderate Customer Service & 12 & OPERATIONS & Stress Efficiency of Oper. & 12 \\
\hline & Pride in Employee Relation & 12 & & High Customer Service & 12 \\
\hline & Employee Compensation is High & 12 & & Improve Employee Relation & 12 \\
\hline & Pride in Employee Benefits & 12 & & Reduce Employee Comp & 12 \\
\hline & Sophisticated Sales Force & 12 & & Unstable Employee Benefits & 12 \\
\hline & Pride in Teamwork & 12 & & Unsophisticated Sales Force & 12 \\
\hline \multirow[t]{2}{*}{ GROWTH } & Aggressive Growth Plans & 12 & GROWTH & Plans to Solidify Niche & 12 \\
\hline & & & & Cautiously/Incrementally & 12 \\
\hline $\mathbf{R} \& \mathbf{D}$ & Invest More in $\mathrm{R} \& \mathrm{D}$ & 12 & $\mathbf{R} \& \mathbf{D}$ & No Product Development & 12 \\
\hline \multirow[t]{3}{*}{ LOCATION } & New Locations & 12 & LOCATION & Seal-Off Portion of Market & 12 \\
\hline & New Ventures & 12 & & Seek Stability & 12 \\
\hline & Horizontal Integration & 12 & & Forward Vertical Integration & 12 \\
\hline \multirow[t]{3}{*}{ TECHNOLOGY } & High Innovation & 12 & TECHNOLOGY & Depend on Single Tech. & 12 \\
\hline & $\begin{array}{l}\text { Broader Range of Information } \\
\text { Needs }\end{array}$ & 12 & & Favor Internally Dev. Tech. & 12 \\
\hline & $\begin{array}{l}\text { Differentiates itself by People } \\
\text { Orientation }\end{array}$ & 12 & & $\begin{array}{l}\text { Differentiates itself by } \\
\text { Technology }\end{array}$ & 12 \\
\hline \multirow[t]{4}{*}{$\begin{array}{l}\text { LOCUS OF } \\
\text { CONTROL }\end{array}$} & $\begin{array}{l}\text { Managers Hired from Marketing } \\
\text { or Product Development }\end{array}$ & 12 & $\begin{array}{l}\text { LOCUS OF } \\
\text { CONTROL }\end{array}$ & $\begin{array}{l}\text { Managers are not necessarily from } \\
\text { Marketing/Production }\end{array}$ & 12 \\
\hline & Sees Success/Failure as & 12 & & See Success/Fail as a & 12 \\
\hline & Contingent on own initiatives & 12 & & function of Environment & \\
\hline & Decentralized Decision Making & 12 & & Centralized Decision Making & 12 \\
\hline \multirow{5}{*}{$\begin{array}{l}\text { ENVIRONMENTAL } \\
\text { UNCERTAINTY }\end{array}$} & Differentiator - seeks to be & & ENVIRONMENTAL & Think External Environment & \\
\hline & $\begin{array}{l}\text { Unique In industry } \\
\text { Environment }\end{array}$ & & UNCERTAINTY & Can be predicted with Certainty & $1 ?$ \\
\hline & $\begin{array}{l}\text { Environment Chabes Kapialy } \\
\text { and Is Unpredictable }\end{array}$ & 12 & & & 12 \\
\hline & Has High Perception of Exclusivity & & & & \\
\hline & Creator of Change & & & & \\
\hline Total & Prospector Points & & Total & Defender Points & \\
\hline
\end{tabular}

Figure 1: Form used in content analysis for STRAT score 
Table 1

\section{Descriptive statistics of dependent variable $(S T R A T)$ and control variable(s) for experimental firms and control firms} for years $t(-3)$ through $t(0)^{a}$

Firms with a Going Concern Opinion ${ }^{\mathrm{b}}(\mathrm{n}=55)$

Year Mean Median Std. Dev.

Firms With an Unqualified Opinion $(\mathrm{n}=55)$

Mean Median Std.Dev. t-value (p-value)

Panel A: STRAT (dependent Variable)

\begin{tabular}{llllllllll}
-3 & 0.7273 & 0.7500 & 0.1519 & 0.6686 & 0.6667 & 0.1405 & 2.105 & $0.038^{* *}$ \\
-2 & 0.7139 & 0.7500 & 0.1974 & 0.6596 & 0.6250 & 0.1756 & 1.524 & 0.130 \\
-1 & 0.6184 & 0.6923 & 0.2498 & 0.6410 & 0.6429 & 0.1924 & -0.530 & 0.597 \\
0 & 0.4136 & 0.4000 & 0.1827 & 0.5793 & 0.5882 & 0.1969 & -4.576 & $0.000^{* * *}$ \\
\hline
\end{tabular}

Panel B: FDIS

\begin{tabular}{rlllllllll}
-3 & -2.505 & -2.581 & 2.094 & -3.057 & -3.096 & 1.838 & -1.471 & 0.144 \\
-2 & -2.597 & -2.925 & 1.630 & -2.829 & -2.924 & 1.574 & -0.757 & 0.451 \\
-1 & -2.414 & -2.521 & 1.627 & -2.646 & -2.589 & 1.429 & -0.794 & 0.429 \\
0 & -0.448 & -1.381 & 4.209 & -2.264 & -2.231 & 1.268 & -3.062 & $0.003 * * *$ \\
\hline
\end{tabular}

Panel C: IND

\begin{tabular}{rllllllll}
-3 & 0.2601 & -.1112 & 1.0829 & 0.7311 & 0.2109 & 1.2485 & -2.113 & $0.037 * *$ \\
-2 & 0.1513 & -.1241 & 0.7753 & 0.7141 & 0.2041 & 1.2713 & -2.803 & $0.006^{* * *}$ \\
-1 & 0.1179 & -.1432 & 0.7508 & 0.7293 & 0.0879 & 1.3032 & -3.015 & $0.003^{* * *}$ \\
0 & 0.0981 & -.1721 & 0.8047 & 0.6869 & 0.0476 & 1.3038 & -2.850 & $0.005^{* * *}$ \\
\hline
\end{tabular}

Panel D: STAB

\begin{tabular}{rlllllllll}
-3 & 0.2364 & 0.000 & 0.4288 & 0.2182 & 0.000 & 0.4168 & 0.225 & 0.822 & \\
-2 & 0.2727 & 0.000 & 0.4495 & 0.2727 & 0.000 & 0.4495 & 0.000 & 1.000 & 0.842 \\
-1 & 0.3273 & 0.000 & 0.4735 & 0.3455 & 0.000 & 0.4799 & -.200 & 0.842 \\
0 & 0.2909 & 0.000 & 0.4584 & 0.2000 & 0.000 & 0.4037 & 1.104 & 0.272 \\
\hline
\end{tabular}

Panel E: SIZE

\begin{tabular}{rllllllll}
-3 & 4.0258 & 3.8278 & 1.5395 & 4.7090 & 4.8086 & 1.5416 & -2.326 & $0.022 * *$ \\
-2 & 4.1333 & 3.9119 & 1.4567 & 4.9962 & 4.8892 & 1.7273 & -2.832 & $0.006 * * *$ \\
-1 & 4.1008 & 3.8503 & 1.4868 & 5.0998 & 5.0137 & 1.7501 & -3.226 & $0.002 * * *$ \\
0 & 3.8221 & 3.7140 & 1.4763 & 5.1236 & 4.8724 & 1.8316 & -4.103 & $0.000^{* * *}$ \\
\hline
\end{tabular}

***Significant at the 0.01 level; ** Significant at $0.05 ; *$ Significant at 0.10

${ }^{a}$ The OPIN variable is not presented since the experimental firms were all coded as 1 for OPIN and the control firms were all coded as 0 for OPIN. Because the standard deviations of both groups are 0 , the $t$-test is not computed.

${ }^{\mathrm{b}}$ The going concern audit opinion was received only in event year 0 . These firms received an unqualified opinion in the prior three years.

An evaluation of the means for experimental firms reveals a decreasing pattern of STRAT as the firm approaches year $\mathrm{t}(0)$ (the year of a first-time GC). This suggests that management reports increasingly more defender-type strategies than prospector-type strategies as the firm approaches the year of receiving a first-time GC. This interpretation is not unreasonable given that management has private information about the firm, and that the private information is reflected in disclosed strategies. It can thus be inferred that managers foresee difficulties and use their insiders' knowledge in disclosing business strategies. These strategies may also provide the auditors with greater insight as to management's plans for a turnaround from existing (emerging) difficulties. 
Table 1, Panel A, shows that experimental firms started out as more prospector type and adjusted their disclosed strategy towards more defender type by the year of a first-time GC. In addition to the clear change in strategy over the previous three years for experimental firms, there is also a highly significant difference $(\mathrm{p}<0.01)$ between experimental firms' STRAT and that of control firms in year t(0). The difference in STRAT is also significant $(\mathrm{p}<0.05)$ in year $\mathrm{t}(-3)$. There is no significant difference in firms' STRAT in years $\mathrm{t}(-1)$ and $\mathrm{t}(-2)$.

The variable $I N D$ is significantly different for each of the four years presented with the control firms showing the overall greater industry dominance over the firms with a first-time GC. There are no significant differences in $S T A B$ (management's stability) between the two groups.

\section{Results Of Cross-Sectional Tests}

The cross-sectional model includes both the experimental firms and the control firms. Table 2, Panel A presents the results of the full cross-sectional model for year $\mathrm{t}(0)$ (the year of the first-time $\mathrm{GC}$ for the experimental firms). Panel B of Table 2 presents the results of the reduced cross-sectional model for year $\mathrm{t}(0)$ with $O P I N$ excluded from the model.

The overall full model (Panel A) for year $\mathrm{t}(0)$ is highly significant $(\mathrm{p}<0.001)$ with adjusted $\mathrm{R}^{2}$ of $16.7 \%$. OPIN is again negative and highly statistically significant $(\mathrm{t}=-4.059 ; \mathrm{p}<0.001)$; suggesting that firms receiving GCs react by disclosing more defender type strategies.

The variable $S T A B$ (representing management's stability) is moderately statistically significant $(\mathrm{p}<0.10)$. These cross-sectional results from $\mathrm{t}(0)$ suggest that there is on average, about an $8 \%$ increase in the disclosed prospector-type business strategies when there is a change in management. This seems intuitively accurate in that new management may find it easier to develop new prospector like strategic plans for the firm's direction as compared to an on-going management that was in place at the time the problems developed. It may also be true that new management may find it easier to place blame on the prior management and therefore seek to outline plans for greater innovation or even adoption of market-driven enthusiasm (prospector-type tendencies). It is interesting to note that DeFond and Jiambalvo (1994) found that $29 \%$ of their firms with increased monitoring and also a debt covenant violation had experienced management change in the year of covenant violation. ${ }^{2}$ No other control variables were statistically significant. The IND and FDIS have positive and negative coefficients respectively.

Table 3 reports the results for the cross-section model covering both the experimental firms and control firms for each of the three years prior to the year of a first-time GCO. These results also mirror, to a large extent, the discussion for each of the variables from the independent samples t-test discussed in the descriptive analysis of variables section of this chapter.

The models for years $t(-1)$ and $t(-2)$ are not found to be statistically significant. In fact none of the control variables were significant for the two years prior to the year of a first-time GC except for FDIS in year $\mathrm{t}(-1)$ that was moderately significant at $\mathrm{p}<0.10$. The alternative model that includes SIZE did not yield results that were much different from those found with the model that excludes SIZE.

The results, however, in Panel $\mathrm{C}$ of Table 3, for year $\mathrm{t}(-3)$ yielded a significant model $(\mathrm{p}<0.05)$ with an adjusted $\mathrm{R}^{2}$ of $7.1 \%$. The only significantly different variables between the two groups in each of the prior years is the TYPE (coded as 1 for firms that had a first-time GC in year $\mathrm{t}(0)$ and a code of 0 for the control firms) and FDIS. It is interesting to note that the coefficient on FDIS is consistently negative and small. The only difference in $\mathrm{t}(-3)$ is that the standard deviation is smaller, i.e. a large $\mathrm{t}$-value. The negative coefficient is consistent with more financial distress leading to more defender type strategies.

\footnotetext{
${ }^{2}$ DeFond and Jiambalvo (1994) use going-concern qualification uncertainty as a proxy for increased monitoring by auditors.
} 
Table 2

Estimated coefficients from the full and reduced cross-sectional regression models examining the incremental effect of OPIN on STRAT for both experimental firms and control firms in year t(0) (excludes SIZE) (n=110)

\begin{tabular}{|c|c|c|c|c|c|}
\hline & Intercept & OPIN & FDIS & IND & STAB \\
\hline \multicolumn{6}{|c|}{ Panel A: Full model (includes OPIN but excludes firm SIZE): } \\
\hline \multicolumn{6}{|c|}{$\operatorname{STRAT}_{i}=b_{0}+b_{1} \operatorname{OPIN}_{i}+b_{2} F D I S_{i}+b_{3} I N D_{i}+b_{4} S T A B_{i}+\varepsilon_{I}$} \\
\hline Coeff. & $0.546^{\mathrm{a}}$ & -0.158 & -0.006003 & 0.006606 & 0.07775 \\
\hline Std Err. & 0.032 & 0.039 & 0.006 & 0.017 & 0.043 \\
\hline t-value & 1.438 & -4.059 & -1.027 & 0.390 & 1.829 \\
\hline p-value & & $(0.000)^{* * *}$ & $(0.307)$ & $(0.697)$ & $(0.070)^{*}$ \\
\hline Adjusted $\mathrm{R}^{2}$ & $16.7 \%$ & & & & \\
\hline F-value & 6.454 & & & & \\
\hline Probability & $0.000 * * *$ & & & & \\
\hline
\end{tabular}

Panel B: Reduced model (excludes $O P I N$ and firm SIZE):

$\begin{array}{lllll}S T R A T_{i}=b_{0}+b_{1} F D I S_{i}+b_{2} I N D_{i}+b_{3} S T A B_{i}+\varepsilon_{i} & & \\ \text { Coeff. } & 0.454^{\mathrm{a}} & -0.01267 & 0.02353 & 0.06513 \\ \text { Std Err. } & 0.025 & 0.006 & 0.018 & 0.045 \\ \text { t-value } & 1.840^{*} & -2.110 & 1.339 & 1.435 \\ \text { p-value } & & (0.037)^{* *} & (0.183) & (0.154) \\ \text { Adjusted } & & & & \\ \text { F-value } & 4.5 \% & & & \\ \text { Probability } & 2.718 & & \end{array}$

Panel C: Results of the $F^{*}$ test (for full and reduced models):

Decision rule: If $F^{*}$ is greater than $\mathrm{F}[(1-\alpha)$; $\mathrm{df}(\mathrm{R})-\mathrm{df}(\mathrm{F}), \mathrm{df}(\mathrm{F})]$ reject the null hypothesis of no incremental information provided by including $O P I N$ in the model. Since $F^{*}=16.48>\mathrm{F}_{\text {crit }}=1.35$, the null is rejected in support of $O P I N$ having incremental information in the model.

Note: Probability values are based on the two-tailed significance test.

${ }^{a}$ Measures the difference between the computed coefficient from regression and the mean expected

STRAT of .50 when a firm discloses an equal number of prospector and defender strategies.

*** $\quad$ Significant at the 0.01 level

** $\quad$ Significant at the 0.05 level

* $\quad$ Significant at the 0.10 level 
Table 3

Estimated coefficients from the full and reduced cross-sectional regression models examining the incremental effect of OPIN on STRAT for both experimental firms and control firms in years $\mathrm{t}(-1)$ through $\mathrm{t}(-3)($ excludes $S I Z E)(\mathrm{n}=110)$

$\operatorname{STRAT}_{i}=b_{0}+b_{1} \operatorname{OPIN}_{i}+b_{2} F D I S_{i}+b_{3} I N D_{i}+b_{4} S T A B_{i}+\varepsilon_{i}$

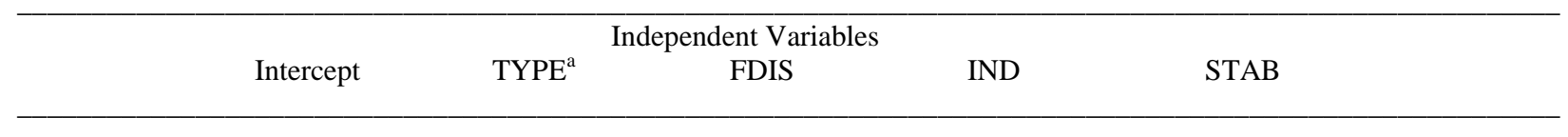

Panel A: $t(-1)$ (one year prior to the year of a first-time going-concern audit modification)

$\begin{array}{llllll}\text { Coeff. } & 0.587 & -0.01643 & -0.02495 & 0.001629 & -0.03746 \\ \text { t-value } & 10.685 & -0.371 & -1.766 & 0.081 & -0.832 \\ \text { p-value } & (0.000)^{* * *} & (0.711) & (0.080)^{*} & (0.936) & (0.408)\end{array}$

Adjusted $\mathrm{R}^{2} \quad 0.5 \%$

F-value $\quad 1.125$

Probability $\quad 0.349$

Panel B: $t(-2)$ (two years prior to the year of a first-time going-concern audit modification)

\begin{tabular}{llllll} 
Coeff. & 0.608 & 0.06146 & -0.01721 & 0.005659 & \multicolumn{1}{l}{-0.00526} \\
t-value & 13.373 & 1.653 & -1.515 & 0.328 & -0.130 \\
p-value & $(0.000)^{* * *}$ & $(0.101)$ & $(0.133)$ & $(0.744)$ & $(0.897)$ \\
& & & & \\
Adjusted $\mathrm{R}^{2}$ & $0.60 \%$ & & & \\
F-value & 1.175 & & & \\
Probability & 0.326 & & & &
\end{tabular}

Panel C: $t(-3)$ (three years prior to the year of a first-time going-concern audit modification)

$\begin{array}{llllll}\text { Coeff. } & 0.601 & 0.07113 & -0.01757 & 0.007143 & 0.03784 \\ \text { t-value } & 19.128 & 2.520 & -2.503 & 0.603 & 1.159 \\ \text { p-value } & (0.000)^{* * *} & (0.013)^{* *} & (0.014)^{* *} & (0.548) & (0.249) \\ & & & & \\ \text { Adjusted } \mathrm{R}^{2} & 7.1 \% & & & \\ \text { F-value } & 3.087 & & & \\ \text { Probability } & 0.019 * * & & & \end{array}$

$\overline{{ }^{a}}$ TYPE is used to distinguish between experimental firms and control firms since OPIN is the same (unqualified opinion) for both groups of sample firms. Type variable was coded 1 for experimental firms and 0 for control firms.

Note: Probability values are based on the two-tailed significance test.

*** Significant at the 0.01 level

** Significant at the 0.05 level

* Significant at the 0.10 level

\section{Validity Assessment Of Dependent Variable}

Based on prior studies and also on the subjective nature of the technique used in determining a firm's disclosed level of strategy, an assessment of the validity of the dependent variable (STRAT) is necessary. An interrater is used to perform content analysis on a sample of annual reports. The inter-rater's scores are correlated with those of the researcher. Several other studies (Botosan, 1997; Bryant 1997; Ahmed 1995) that have used a 
disclosure score or a disclosure index have performed similar assessments. These studies have presented consistently strong and corroborative findings.

The inter-rater ${ }^{3}$ was furnished with a sample of 25 annual reports and the content analysis forms and asked to perform content analysis by rating the disclosed strategies in the annual reports. The inter-rater was not informed which of the 25 firms were experimental firms and which were control firms. In addition, the auditor's opinion was not included in the annual reports given to the inter-rater.

Based on the Pearson's and Spearman's correlation analysis the results show that approximately $50 \%$ of the inter-rater's STRAT scores were higher than those of the researcher, with STRAT score differences of less than 0.009. The results show all individual scores as strongly and positively correlated $(\mathrm{p}<0.01)$. The correlations obtained in this study should mitigate concerns of possible error in content analysis and classification of disclosed business strategy.

\section{Summary And Conclusion}

In this study, an investigation of the association between GCs and changes in management's disclosed business strategy is performed. Based on selective review of literature from strategy and auditing disciplines, a model that tests for an association of a GC on business strategy disclosure is developed.

After controlling for other variables such as the financial distress level, firm size, management's stability, and industry dominance, the results indicate an association between a first-time GCs and changes in firms' reported business strategy. The descriptive statistics and cross-sectional tests also reveal that management begins disclosing more defender type strategies about two years prior to the year of the first-time GC. It may be an indicator that auditors begin expressing concerns about the firm's ability to survive as far back as two years before the GC. While the experimental firms show a sharp turn towards disclosing more of defender type strategies in year $\mathrm{t}(0)$, the control firms show a very moderate decline in their disclosed strategies although still disclosing more prospector than defender type strategies.

The results also indicate that financial distress does not completely explain the change in strategy. In years when the experimental firms did not receive a GC, the financial distress level was not significantly different from those of the control firms and yet the control firms did not eventually experience a first-time GC. In year $t(0)$, however, the financial distress level is significantly different between the two groups of sample firms. ${ }^{4}$ The results indicate GC to be statistically significant in that year. The implication is that management considers other than financial distress factors in their decision to adjust their business strategies. The model points to the GC as a factor that influences management's choice of business strategies to disclose since this variable is statistically significant. The negative coefficient indicates that the GC is associated with shifts from prospector like strategies towards defender like strategies.

A change in management was found to elicit disclosure of more prospector type strategies. It is possible that new management may choose to adopt new strategies as soon as possible in order to chart a new direction for the firm. It also seems plausible that this is an ideal opportunity for new management to express their leadership style through their choice of business strategies to emphasize.

\section{Limitations And Continued Research}

The findings in this study should be interpreted in light of potential limitations, which in turn point toward avenues for future research. First, common factors may underlie the issuance of a GC and the level of a firm's financial distress. GC and financial distress level are both independent variables in this study and could be based in

\footnotetext{
${ }^{3}$ To enhance the quality of the results, the selected inter-rater is a doctoral student with a major in Strategy. It is assumed that selecting a strategy major enhanced the reliability of the interpretation of STRAT measure.

${ }^{4}$ As previously noted, when the three extreme values in FDIS are removed, there is no significant difference between the FDIS values for experimental firms and control firms.
} 
part on omitted common factors in tests performed in this study. A possible alternative specification to the model is to include an additional variable for drifts in the stock price (market). This variable would help to account for changes in STRAT that may be related to management's sensitivity to changes in stock prices. Although this study has attempted to identify the appropriate control variables in the regression tests, it is still possible that the results obtained could be confounded by omitted variables.

Second, the reliance on researcher's content analysis for the strategy variable may introduce bias into the study although this problem was mitigated by dual-raters. The use of multi-methods to enhance the validity/reliability of the strategy measure may be a desirable future consideration. Additionally, since strategies are quite a complex phenomena, multi-dimensional measures of strategy and more elaborate measures of strategy should be developed in order to clearly discriminate among more than just the defender and prospector type strategies. In fact, researchers can enhance the validity of strategy scores by relying on multiple sources of information.

Third, a larger sample, extending beyond the four years' analysis in this study may reveal other patterns that were not uncovered in this study. More specifically, it is not clear what strategy experimental firms pursue in the years after the removal of the GC. An extension of this study to include the years after a first-time GC would provide further insights as to the continued effect of audit opinions on business strategy. A question to be answered is, what strategy disclosures do management report in the years immediately subsequent to the year of lifting of the $\mathrm{GC}$ when the firms receive an unqualified opinion?

Finally, opportunities for increasing our understanding of the connection between management's choice of business strategies and other accounting related issues are great. These issues may encompass the relation between strategies and specific accounting controls, the budgeting process (for cost conscious managers), and performance based compensation schemes that are based on management's plans and eventual outcomes.

\section{References}

1. Ahmed, K. 1995. The effect of corporate characteristics on disclosure quality in corporate annual reports: A metaanalysis. Working paper, Victoria University of Wellington, New Zealand, cited in Botosan, C.A., 1997. Disclosure level and the cost of equity capital. The Accounting Review, 72, 3, 336.

2. AICPA. 1994. Improving Business Reporting - A Customer Focus: A Comprehensive Report of the Special Committee on Financial Reporting. New York, NY: AICPA.

3. Amir, E., and B. Lev. 1995. Value-relevance of nonfinancial information: The wireless communications industry. Journal of Accounting and Economics, "Conference on Contemporary Financial Reporting Issues" (October): 1-42.

4. Anderson, S.W., and K. Sedatole. 1998. Designing quality into products: The use of accounting data in new product development. Accounting Horizons, 12, 3 (September), 213-233.

5. Asare, Stephen K. 1990. The auditor's going-concern decision: A review and implications for future research. Journal of Accounting Literature, 9, 39-64.

6. Bagby, J.W., M.R. Kintzele, and P.L. Kintzele. 1988. Management discussion of business performance: An analytical and empirical evaluation. American Business Law Journal, 26/1, (Spring): 57-98.

7. Bell, T.B. and R.H. Tabor. 1991. Empirical analysis of audit uncertainty qualifications. Journal of Accounting Research, 29, Autumn, 350-370.

8. $\quad$ Bell, T. B., F. O. Marr, I. Solomon and T. Howard. 1997. Auditing Organizations Through a Strategic-Systems Lens. The KPMG Business Measurement Process. KPMG Peat Marwick LLP.

9. Botosan, C.A. 1997. Disclosure level and the cost of equity capital. The Accounting Review, 72, 3, 323-349.

10. Bryan, S.H. 1997. Incremental information content of required disclosures contained in management discussion and analysis. The Accounting Review, 72, 2, 285-301.

11. Christie, A. A. and J. L. Zimmerman. 1994. Efficient and opportunistic choices of accounting procedures: Corporate control contests. The Accounting Review, 69: 539-566.

12. DeChow, P. M., R. G. Sloan and A. P. Sweeney. 1995. Detecting earnings management. The Accounting Review, 70: 193-225.

13. DeFond M., and J. Jiambalvo.1994. Debt covenant violation and manipulation of accruals. Journal of Accounting and Economics, 17: 145-176.

14. Dieter, R., and K. Sandefur. 1989. Spotlight on management's discussion and analysis. Journal of Accountancy, December: $78-87$. 
15. Gibson, C., and N. Schroeder. 1990. Readability of management discussion and analysis. Accounting Horizons, 4, December, 78-87.

16. Gosselin, M. 1997. The effect of strategy and organizational structure on the adoption and implementation of activitybased costing. Accounting, Organizations and Society, Vol. 22, No. 2, 105-122.

17. Ittner, C. D., D. F. Larcker and M. V. Rajan. 1997. The choice of performance measures in annual bonus contracts. The Accounting Review, 72, 2, 1-24.

18. Jones, F. L. 1987. Current techniques in bankruptcy prediction. Journal of Accounting Literature, 6, $131-164$.

19. 1996. The information content of the auditor's going concern evaluation. Journal of Accounting and Public Policy, 15, 1-27.

20. Lev, B. and S.R. Thiagarajan. 1993. Fundamental information analysis. Journal of Accounting Research, 31, Autumn, $190-215$.

21. Miles, R.E. and C.C. Snow. 1978. Organizational Strategy, Structure, and Process. McGraw-Hill, NY.

22. Shrivastava, P. and S.A. Nachman. 1989. Strategic leadership patterns. Strategic Management Journal, $10,51-66$.

23. Snow, C. C. and D. C. Hambrick. 1980. Measuring organizational strategies: Some theoretical and methodological problems. Academy of Management Review, 5, 4, 527-538.

24. Snow, C. C. and L. G. Hrebiniak. 1980. Strategy, distinctive competence, and organizational performance. Administrative Science Quarterly, 25, 317-336.

25. Sweeney, A. P. 1994. Debt-covenant violations and managers' accounting responses. Journal of Accounting and Economics, 17, 281-308.

26. Young, M.A. 1989. Research notes and communications sources of competitive data for the management strategist. Strategic Management Journal, 10, 285-293.

27. Zmijewski, M. E. 1984. Methodological issues related to the estimation of financial distress prediction models. Journal of Accounting Research, 22 (Supplement): 59-82.

Notes 
Notes 